\title{
Continuous vertical aerosol profiling with a multi-wavelength Raman polarization lidar over the Pearl River Delta, China
}

\author{
Birgit Heese $^{1}$, Holger Baars ${ }^{1}$, Stephanie Bohlmann ${ }^{1}$, Dietrich Althausen ${ }^{1}$, and Ruru Deng ${ }^{2}$ \\ ${ }^{1}$ Leibniz Institute for Tropospheric Research (TROPOS), Permoserstraße 15, 04318 Leipzig, Germany \\ ${ }^{2}$ School of Geography and Planning, Sun Yat-sen University, Guangzhou, China \\ Correspondence to: Birgit Heese (heese@ tropos.de)
}

Received: 12 August 2016 - Discussion started: 11 October 2016

Revised: 17 March 2017 - Accepted: 1 April 2017 - Published: 7 June 2017

\begin{abstract}
A dataset of particle optical properties of the highly polluted atmosphere over the Pearl River Delta (PRD), Guangzhou, China, is presented in this paper. The data were derived from the measurements of a multiwavelength Raman and depolarization lidar Polly ${ }^{\mathrm{XT}}$ and a co-located AERONET sun photometer. The measurement campaign was conducted from November 2011 to midJune 2012. These are the first Raman lidar measurements in the PRD that lasted for several months.

A mean value of aerosol optical depth (AOD) of $0.54 \pm 0.33$ was observed by the sun photometer at $500 \mathrm{~nm}$ in the polluted atmosphere over this megacity for the whole measurement period. The lidar profiles frequently show lofted aerosol layers, which reach altitudes of up to 2 to $3 \mathrm{~km}$ and, especially during the spring season, up to $5 \mathrm{~km}$. These layers contain between 12 and $56 \%$ of the total AOD, with the highest values in spring. The aerosol types in these lofted layers are classified by their optical properties. The observed lidar ratio values range from 30 to $80 \mathrm{sr}$ with a mean value of $48.0 \pm 10.7 \mathrm{sr}$ at $532 \mathrm{~nm}$. The linear particle depolarization ratio at $532 \mathrm{~nm}$ lies mostly below $5 \%$, with a mean value of $3.6 \pm 3.7 \%$. The majority of the Ångström exponents lie between 0.5 and 1.5 , indicating a mixture of fine- and coarsemode aerosols.

These results reveal that mostly urban pollution particles mixed with particles produced from biomass and industrial burning are present in the atmosphere above the Pearl River Delta. Trajectory analyses show that these pollution mixtures arise mainly from local and regional sources.
\end{abstract}

\section{Introduction}

The Pearl River Delta (PRD) in the south-east of China is one of the largest urbanized areas in the world. High population density and a very strong economy leads to an almost permanent high aerosol load in the whole area around the city of Guangzhou in the PRD. The consequences for geographical development, people's health, and atmospheric pollution were studied in the framework of the German project "Megacities-Megachallenges - Informal Dynamics of Global Change". The atmosphere over the PRD is influenced by high urban and industrial activity but is also affected by the vicinity of the sea. Hence, the predominant atmospheric particles expected to be found in this area are a mixture of different aerosol types such as urban haze, burning products from traffic and industry, and sea-salt particles.

The visibility in Guangzhou has significantly decreased during the last 4 decades. Since 1972 the number of days with low visibility has increased from a few days per year to about 100-150 days per year from 1980 to 2006 (Deng et al., 2008). The authors could relate the low visibility to the increasing particle concentration observed from in situ particle measurements during a case study in November 2005, where both high- and low-visibility episodes occurred. They found that $70 \%$ of the visibility is reduced by small scattering particles and $20 \%$ by absorbing particles. A comprehensive overview of the air pollution at ground level since 1990 in megacities in China is given in Chan and Yao (2008). They found that particles arising from traffic, industry, wood burning, and coal burning are the major pollutants most of the time in the PRD, and they can cause high pollution episodes and low visibility. These types of in situ studies have revealed 
valuable information about the particle types and concentrations measured at ground level that contribute to the severe air conditions in the PRD and other megacities. However, what is the vertical distribution of these particles?

Only a limited number of vertically resolved aerosol observations were available over south-eastern China until the beginning of this century. The Asian dust lidar network was established in the late 1990ies (Murayama et al., 2001), with lidar stations mainly in Japan and occasionally in China. For example, a short-term study was conducted in July 2006 during the PRD2006 campaign (Sugimoto et al., 2009). Here, a two-wavelength, backscatter and polarization lidar from the National Institute for Environmental Studies (NIES) in Japan was used. Two typhoon-driven flow episodes of northern air, periods of accumulation of air pollution within the PRD area, and three cases of lofted layers above the planetary boundary layer (PBL) were observed. This lidar remained in Guangzhou until March 2009 and was used for a long-term study on seasonal aerosol variations (Hara et al., 2011).

The first Raman lidar measurements in the PRD were carried out by TROPOS during a 1-month intensive field campaign in Xinken in October 2004 (Tesche et al., 2007). The lidar used was the prototype Raman lidar Polly with just one wavelength and two detection channels. High levels of aerosol load and the presence of lofted aerosol layers were observed during the entire period (Ansmann et al., 2005).

In November and December 2009, as part of the Megacities project, a first short field campaign took place in Zhongshan in the southern part of the PRD. During this campaign a Raman lidar of the Anhui Institute of Optics and Fine Mechanics, Hefei, China, and a sun photometer from TROPOS were deployed. To contrast the different aerosol conditions, two significant events of moderate and hazy pollution were characterized in detail by Chen at al. (2014). To investigate the aerosol conditions of this highly polluted area over a longer time period and to study the inter-seasonal differences, long-term observations in the PRD were realized in the framework of the Megacities project. The campaign was performed from autumn 2011 until summer 2012 in Guangzhou. The multi-wavelength Raman lidar Polly XT (Althausen et al., 2009) with depolarization capabilities was used for the characterization of the aerosol types over the PRD. The results are presented in this paper. To our knowledge, this is the first time that continuous Raman lidar observations have been performed in the PRD for more than half a year. This provides a unique dataset of the vertical aerosol distribution, including the characterization of the optical properties in this area.

In Sect. 2 the campaign details are given, the instrumental set-up is described, and the climatic conditions are outlined. In Sect. 3 a seasonal overview over the lidar and sun photometer measurement results is given and a case study of particularly high aerosol content in the vertical profile is presented. In Sect. 4 the layered structure of the aerosol is analysed, the aerosol is classified by lidar optical properties, and the origin of the observed aerosol is examined by trajectory cluster analysis. A statistical analysis of the measured optical properties is presented as well, and finally, a conclusion is given.

\section{Experiment}

\subsection{Field site}

The measurements for the vertically resolved aerosol characterization were taken by a multi-wavelength Raman lidar Polly ${ }^{X T}$ (Althausen et al., 2009; Engelmann at al., 2016) of TROPOS and a dual-polar sun photometer CE-318dp (Cimel) from AERONET (Holben et al., 1998). Both instruments were deployed on the rooftop of a laboratory building on the east campus of Sun Yat-sen University of Guangzhou $\left(23^{\circ} 04^{\prime} 08^{\prime \prime} \mathrm{N}, 113^{\circ} 22^{\prime} 52^{\prime \prime} \mathrm{E}\right.$; $23.5 \mathrm{~m}$ above sea level). The lidar was deployed on a roof terrace on the last floor of the building with easy access from the adjacent laboratories. The sun photometer was deployed on the flat rooftop of the building, with an undisturbed $360^{\circ}$ panoramic view. The sun photometer measurements started in the end of October 2011 and lasted until the beginning of July 2012. The lidar ran in a continuous $24 / 7$ measurement mode from the beginning of November 2011 until mid-June 2012 - only interrupted by rain periods. In the case of rain, a sensor detects the falling rain drops and the system closes down the measurements immediately. The vertical resolution of the raw profiles is $7.5 \mathrm{~m}$ and the data were stored with a temporal resolution of $30 \mathrm{~s}$.

The optical properties measured by the lidar are the particle backscatter coefficient at 355,532 , and $1064 \mathrm{~nm}$; the particle extinction coefficient at 355 and $532 \mathrm{~nm}$; and the linear depolarization ratio at $532 \mathrm{~nm}$. For the determination of the particle backscatter coefficient and particle extinction coefficient at night, the Raman method (Ansmann et al., 1992) was applied. During the day the Fernald-Klett method (Fernald, 1984; Klett, 1981) was used, but in this study only the Raman-derived profiles were taken into account. The linear total or volume depolarization ratio includes molecular depolarization effects. The linear particle depolarization ratio was calculated using the $90^{\circ}$ calibration method described in detail by Freudenthaler et al. (2009). Further optical properties derived were the extinction-to-backscatter-coefficient ratio, also called the lidar ratio; the linear particle depolarization ratio; the aerosol optical depth (AOD); and the respective backscatter- and extinction-related Ångström exponents.

These properties were used to identify the type of aerosol that was observed. While the particle backscatter coefficient indicates the present number of particles, depending on their scattering abilities, the particle extinction coefficient also relates to the absorption abilities of the particles. The lidar ratio, the ratio between these coefficients, is dependent on the particle type, not on the quantity. Also, the particle depolarization ratio is typical for the particle type and helps to dis- 
tinguish between spherical and non-spherical particles. The Ångström exponent describes the wavelength dependence of the respective backscatter and extinction coefficients and is dependent on the size distribution of the particles.

The lidar data were analysed as follows: the data were visually cloud screened using the automatically produced quick-look images on the Polly ${ }^{N E T}$ web page: http://polly. tropos.de. Then, these data were evaluated manually in intervals of 2 to $3 \mathrm{~h}$ to obtain comparable profiles for a statistical analysis. To avoid over-representation of long-lasting cloudfree periods with constant aerosol conditions, the number of considered profiles per day during such periods was reduced to a maximum number of four.

The lidar data presented here are without any overlap correction. The overlap function could not be calculated due to permanently high aerosol load in the atmosphere over the PRD. However, to be able to calculate the AOD from the lidar profiles, the Raman backscatter profiles were fitted to the Raman extinction profiles at the heights below $1.5 \mathrm{~km}$ height. The Raman backscatter profiles are not affected by the incomplete overlap since a ratio of two channels is used in the algorithm. Finally, the lowermost extinction value at about $150 \mathrm{~m}$ height was extrapolated to the ground level.

The sun photometer measures the direct and indirect Sun radiation at nine wavelengths from 340 to $1640 \mathrm{~nm}$ every $15 \mathrm{~min}$ when the Sun is visible. In addition, with this dualpolar instrument, the radiances at three different depolarization directions are measured by means of a second filter wheel ( $\mathrm{Li}$ et al., 2009). However, the data used in this study are derived solely from direct Sun measurements. The products used are the AOD and the Ångström coefficients derived by AERONET, available from the AERONET web page: http://aeronet.gsfc.nasa.gov.

\subsection{Atmospheric conditions}

The atmospheric conditions of the PRD are controlled by a subtropical climate characterized by warm winters and hot and humid summers. The monthly mean temperatures are coldest in January with $13.9^{\circ} \mathrm{C}$ and warmest in July with $28.8^{\circ} \mathrm{C}$. The annual mean temperature is $22.4^{\circ} \mathrm{C}$. The weather is influenced by the Asian monsoon circulation. The main wind direction turns with the dislocation of the Intertropical Convergence Zone (ITCZ) from north and northeasterly winds during the winter months to southerly winds during the summer months. Due to the strong solar irradiance in summer, a trough is formed above the continent and warm and moist air masses are transported from the South China Sea over the continent. The mean annual precipitation is $1720 \mathrm{~mm}$. In the rainy season, which lasts from April to September, monthly mean precipitation rates range from 100 to $300 \mathrm{~mm}$ per month. During winter the solar irradiance is low, which cools down the continent. This results in a continental anticyclone that transports dry air masses southward.
During the winter months, the monthly mean precipitation lies between 30 and $90 \mathrm{~mm}$ (Climate Data, 2012).

The rainfall pattern during the winter and spring season of 2011/2012 was different. After initially strong rainfall in November 2011, dry weather prevailed, so that no precipitation was registered in December 2011. From January 2012 to mid-March 2012 there were numerous days with precipitation, resulting in $105 \mathrm{~mm}$ in January, $74 \mathrm{~mm}$ in February, and $66 \mathrm{~mm}$ in March 2012 (National Climatic Data Center, 2012). This was caused by a less-pronounced continental high pressure, so that not dry air masses from the continent but moist air masses arriving from the sea were dominant. The increased precipitation activity in south-eastern Asia in 2012 is also attributed to the strong La Niña event in 20102012 (e.g. Boening, 2012). In April 2012 the monsoon season started in Guangzhou, with the area receiving more than $1000 \mathrm{~mm}$ precipitation until June 2012. The climatological mean value for April-June is around $700 \mathrm{~mm}$.

\section{Temporal and vertical aerosol distribution}

In this section we present several aspects of the aerosol observations: first, an overview of the temporal development of the aerosol distribution over the entire measurement period is given by the AOD measured by the lidar and sun photometer. A case study of the highly polluted atmosphere using the lidar profiles shows the typical aerosol distribution with lofted aerosol layers, which contain a considerable amount of the total aerosol. Finally, seasonal mean profiles were calculated from all particle extinction profiles to identify seasonal patterns in the vertical aerosol distribution.

\subsection{Total AOD}

An overview of the aerosol conditions during the entire observation period is given by the derived AOD values. Figure 1 shows the AERONET (Holben et al., 1998) level 2 AOD values at $500 \mathrm{~nm}$ measured by the sun photometer and the AOD values derived from Polly ${ }^{\mathrm{XT}}$ Raman extinction profiles at $532 \mathrm{~nm}$. The combination of the sun photometer working only during the day and the Raman capabilities for lidar available at night offers the unique possibility of obtaining a continuous time series of AOD whenever atmospheric conditions allow for it. The extrapolation procedure to calculate the AOD from the lidar profiles seems to underestimate the amount of aerosol close to the ground since it leads to slightly lower AOD values from the lidar than the ones measured by the sun photometer. Conversely, the sun photometer AOD measurements may be influenced by more humidity during the day. 


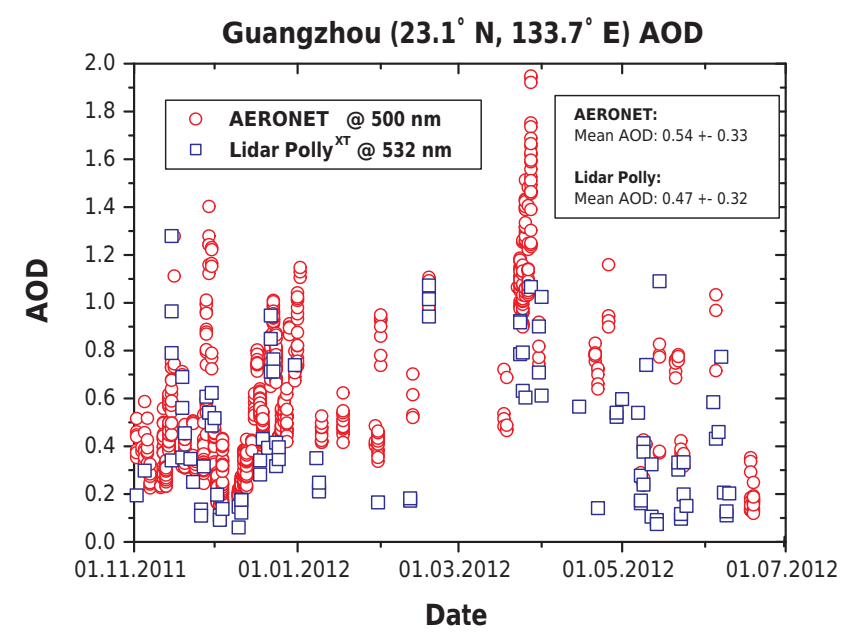

Figure 1. AOD derived from Polly ${ }^{X T}$ Raman extinction measurements at $532 \mathrm{~nm}$ and AERONET level 2 AOD derived from sun photometer measurements at $500 \mathrm{~nm}$.

During November and December 2011, sun photometer AOD values are available on 17 and 22 days, respectively. After this period a lot of rain and cloudy weather was present over Guangzhou. As a consequence, for 2012, level 2 sun photometer AOD measurements are only available on 28 days in total. However, these data still provide an overview of the development of the aerosol content throughout the observation period. In the beginning of the observations, in November and December 2011, most AOD values ranged between 0.2 and 0.6 , with some peak AOD periods with high values of up to 1.4. The monthly mean AOD in November was moderate, with AOD values of 0.45 measured by the sun photometer and 0.49 measured by the lidar. In December these AOD values were 0.49 and 0.39 (sun photometer and lidar). In January ( $\mathrm{AOD}=0.57$ and 0.24 ) and in February $2012(\mathrm{AOD}=0.93$ and 0.67$)$ only a few observations were available to calculate the mean values, which were higher than in November and December. Unusually heavy rainfall was observed, which seemed to be triggered by the strong La Niña event during that winter. In March 2012, a period with very high AOD values started to evolve. The monthly mean AOD measurements of 1.16 and 0.84 were the highest values reached during this field campaign. This is plausible since no more precipitation was observed that could remove the particles from the atmosphere.

The maximum AOD of 1.95 was measured by the sun photometer on 28 March 2012, which is a very high value compared to the rest of the time series. This high AOD may be the result of hygroscopic growth at the top of the boundary layer, which was observed by the lidar at the time of this measurement and may not be identified by the sun photometer. Towards the summer season, with the onset of the monsoon, the mean AOD decreased to 0.82 and 0.60 in April and 0.49 and 0.34 in May. At the beginning of June, the mean AOD values were 0.32 and 0.36 . For the whole observation period, the mean photometer AOD value at $500 \mathrm{~nm}$ was $0.54 \pm 0.33$ and the lidar AOD value at $532 \mathrm{~nm}$ was $0.47 \pm 0.32$. This is a little higher than the mean AOD derived from the only other long-term lidar observations in Guangzhou. Hara et al. (2011) measured an annual mean AOD of 0.41 at $532 \mathrm{~nm}$ and observed seasonal AOD variation with peaks in spring and autumn. These mean AOD values indicate a generally high mean background level of aerosol in the atmosphere above the PRD. For comparison, in Leipzig, Germany, a continental central European site, the yearly mean AOD measured by a sun photometer during recent years lies between 0.15 and 0.19 at $500 \mathrm{~nm}$.

\subsection{Case study}

Figure 2 shows the temporal evolution of the attenuated backscatter coefficient (calibrated range-corrected signal) at $1064 \mathrm{~nm}$ for a 5-day period from 23 to 29 March 2012 in panel (a). The colours range from low backscatter signal in blue to high backscatter signal in red. White colours that can be seen on top of the aerosol layers indicate mostly clouds. The blue vertical stripes occur if no signal is measured at all, as for example during a precipitation event on 23 March starting around 16:00 UTC. Several precipitation periods follow until about 10:00 UTC the next day. This plot shows the evolution of the aerosol layers that persist over these days. The PBL develops every day starting around 00:00 UTC (08:00 LT) and reaches heights of up to about $2-2.5 \mathrm{~km}$ at its maximum. Above the PBL, another aerosol layer is visible, which reaches from 2 to $5.5 \mathrm{~km}$ at the beginning of the period and to $5 \mathrm{~km}$ during the following 2 days. The large heights of the lofted layers, as observed in this case, were mostly reached in spring. In Fig. $2 b$ the volume depolarization ratio at $532 \mathrm{~nm}$ is shown. Green and yellow colours show considerable volume depolarization ratios. A narrow layer of elevated depolarization ratio is visible just above $2 \mathrm{~km}$ height. This layer corresponds to the lower boundary of the observed lofted layer.

Lidar profiles of the derived optical properties for 26 March 2012 from 18:00 to 20:30 UTC are presented in Fig. 3. The profiles of the particle backscatter coefficient, the particle extinction coefficient, and the resulting lidar ratio; a backscatter-related Ångström exponent; and the linear particle depolarization ratio are shown. Local time of this measurement is 02:00-04:30. The nocturnal PBL shows a two-layer structure with higher particle backscatter and extinction coefficients below $1 \mathrm{~km}$ towards the ground and lower values between 1 and $2 \mathrm{~km}$ height. From 2 to $5 \mathrm{~km}$ height, the pronounced lofted aerosol layer is visible, with high values of the particle extinction coefficient of up to $300 \mathrm{Mm}^{-1}$ at $532 \mathrm{~nm}$. The mean lidar ratio of the lofted layer is $45.8 \pm 7.5 \mathrm{sr}$ at $355 \mathrm{~nm}$ and $51.7 \pm 8.3 \mathrm{sr}$ at $532 \mathrm{~nm}$. The Ångström exponent shows values around 1.5 throughout the whole profile. The particle depolarization ratio is about $9 \%$ 
(a) Attenuated backscatter coefficient at $1064 \mathrm{~nm}$

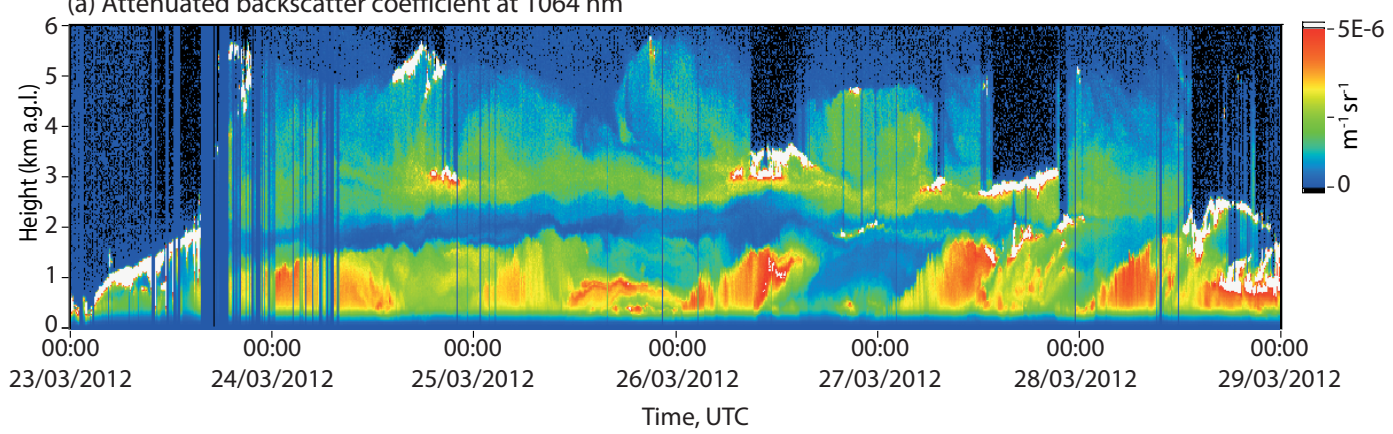

(b) Volume depolarization ratio at $532 \mathrm{~nm}$

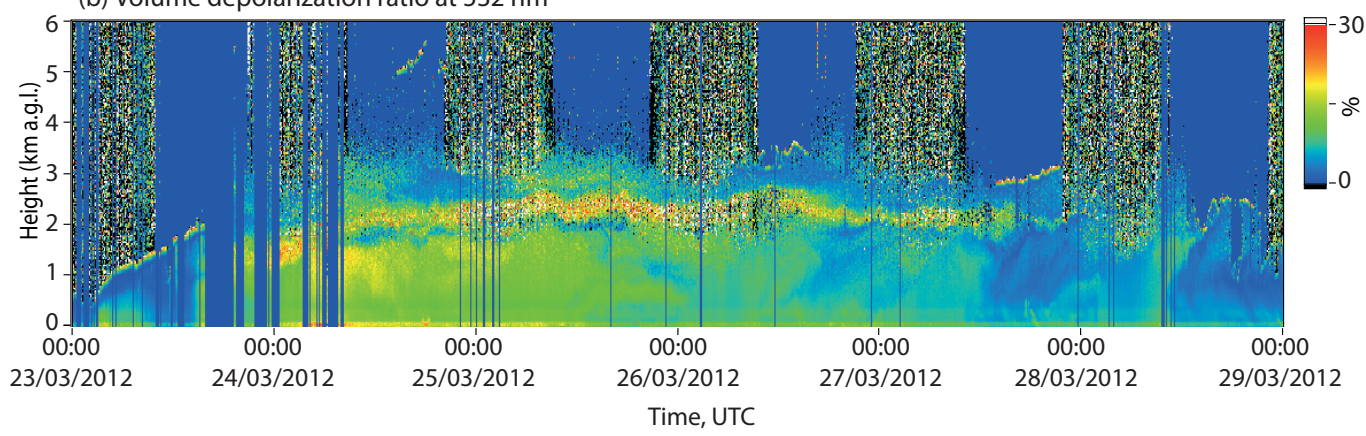

Figure 2. Attenuated backscatter coefficient at $1064 \mathrm{~nm}$ (a) and volume depolarization ratio at $532 \mathrm{~nm}$ (b) for the 5-day period from 23 to 28 March 2012. The blue, vertical lines in the plots occur when the laser is automatically switched off due to rain events. This may also be caused by insects flying through the rain sensor.

below $2 \mathrm{~km}$ height and increases to $15 \%$ below the lofted aerosol layer before it decreases to less than $5 \%$ inside the lofted layer.

Figure 4 shows HYSPLIT $48 \mathrm{~h}$ backward trajectories calculated for arrival heights of 500, 2200, and $3000 \mathrm{~m}$. The heights represent the observed layer structure, where $500 \mathrm{~m}$ is inside the lower PBL; $2200 \mathrm{~m}$ is the lower part of the lofted layer, where the depolarization ratio is elevated; and $3000 \mathrm{~m}$ is at the maximum of the particle backscatter and extinction coefficient values inside the lofted layer.

All trajectories remained quite close to the measurement site for the last $48 \mathrm{~h}$. The trajectory at $500 \mathrm{~m}$ came from the South Chinese Sea, bringing some air with lower pollution levels. The trajectory arriving at $2200 \mathrm{~m}$ height stayed closest to the measurement site. It came from the north and circled above the measurement site at the same height for 1 day. The trajectory arriving at $3000 \mathrm{~m}$ represents the lofted layer. It rose from ground level just the day before and came from local and regional sources north-west of the measurement site.

This observed structure of particle layers frequently occurred above the measurement site: a PBL with a depth of 1.5 to about $2 \mathrm{~km}$ and a decoupled, lofted aerosol layer above. The lofted layers in this case study had a depth of 2.5 to $3 \mathrm{~km}$, which was the highest depth observed. Typically these lofted layers had a depth between 1 and $2 \mathrm{~km}$. The top boundaries of the lofted layers lay between 1.5 and $5.5 \mathrm{~km}$, as in this ex-

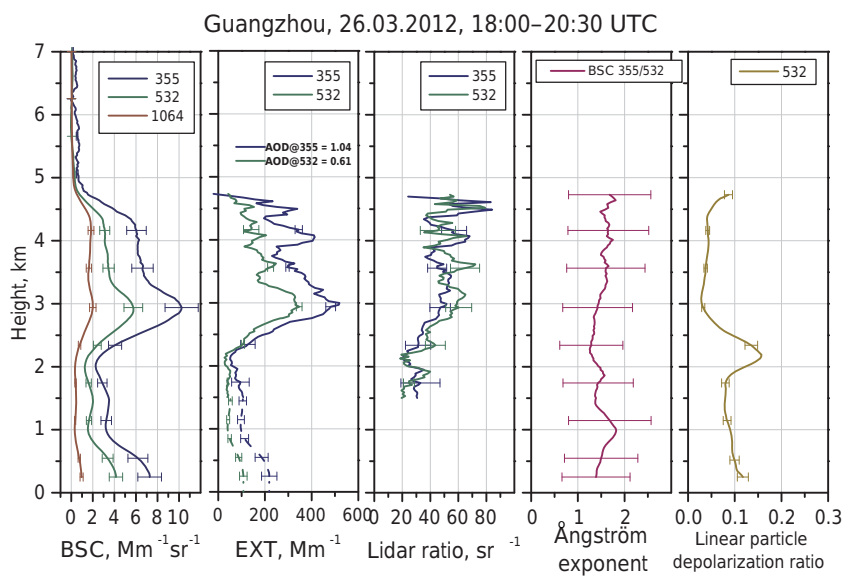

Figure 3. Lidar optical property profiles of particle backscatter coefficient (BSC), particle extinction coefficient (EXT), lidar ratio, backscatter-related Ångström exponent at 355-532 nm, and linear particle depolarization ratio at $532 \mathrm{~nm}$ derived from Polly XT measurement on 26 March 2012 (local time is UTC $+8 \mathrm{~h}$, 02:00 to 04:30 LT). The profiles are vertically smoothed over 15 range bins, which correspond to $450 \mathrm{~m}$. The dashed prolongation of the particle extinction profiles towards the ground results from fitting the BSC to the EXT profile and extrapolating to the ground. 


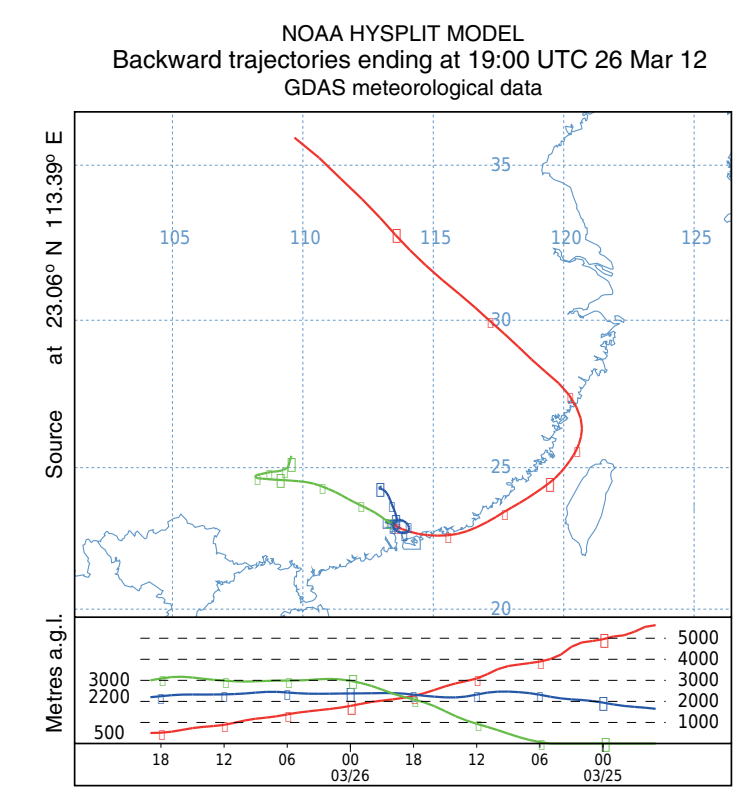

Figure 4. Trajectory analysis for 26 March 2012, $48 \mathrm{~h}$ back in time, arriving at $500 \mathrm{~m}$ inside the boundary layer, at $2200 \mathrm{~m}$ below the lofted layer, and at $3000 \mathrm{~m}$ inside the lofted layer.

ample. The optical properties of these lofted aerosol layers will be discussed in more detail in Sect. 4.

\subsection{Mean profiles}

An overview of all evaluated lidar profiles of the particle extinction coefficient at $532 \mathrm{~nm}$ is plotted in Fig. 5. In total, 99 single profiles (plotted in grey) were considered for this analysis. To identify seasonal variations in the profile shape, four mean profiles averaged over 2 months each were calculated and are plotted in bold, coloured lines. Note that the scale of the $x$ axis is as high as $1000 \mathrm{Mm}^{-1}$ in this plot.

The mean November-December profile was calculated from 35 single profiles. It shows a smooth decrease in the particle extinction coefficient with height, which reached zero values at about $4 \mathrm{~km}$. The highest value in the boundary layer was $275 \mathrm{Mm}^{-1}$ at $300 \mathrm{~m}$, which is the lowermost height of the profiles.

The mean January-February profile results from 11 single profiles only, which is due to the unusual rainy season that winter. The mean profile shows two minima at 1.5 and $2 \mathrm{~km}$ height and a weak mean lofted layer between 2 and $4 \mathrm{~km}$. Further inspection of the single profiles shows that three cases with pronounced lofted layers at the end of February are included here. Also, the mean January-February profile reached zero values at about $4 \mathrm{~km}$ height. The largest PBL value of the mean particle extinction coefficient was as high as $500 \mathrm{Mm}^{-1}$, which is the highest seasonal mean value.

The mean March-April profile calculated from 20 single profiles is the most outstanding. The decrease in the PBL is less pronounced and a clear lofted layer is present be-

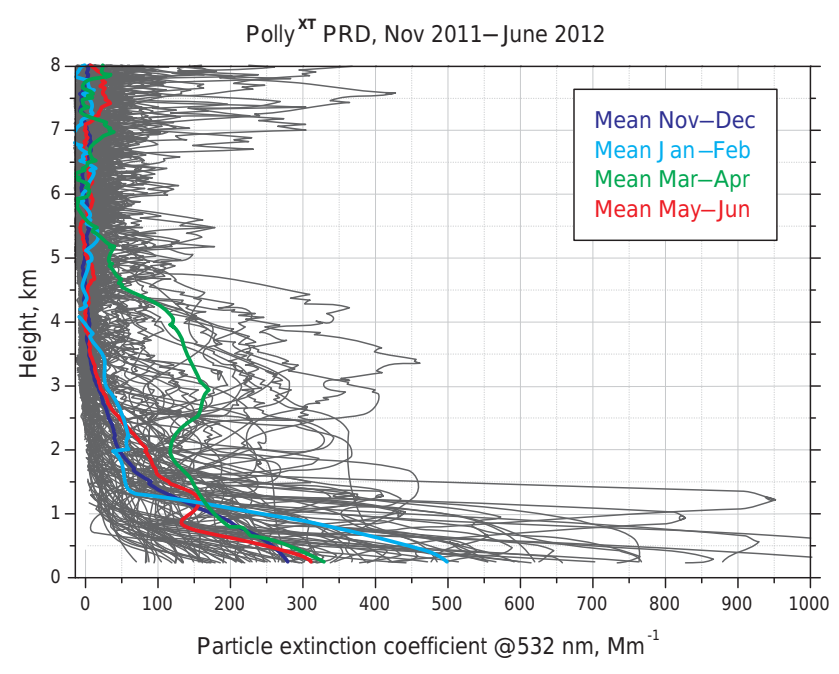

Figure 5. All single and seasonal mean particle extinction coefficient profiles measured by the lidar at $532 \mathrm{~nm}$ during the entire observation period from November 2011 to June 2012.

tween 2 and $4.5 \mathrm{~km}$ height, with particle extinction coefficients of up to $170 \mathrm{Mm}^{-1}$ at $2.9 \mathrm{~km}$ height. This is more than 4 times the values for the three other mean profiles. In total, the mean March-April profile reached zero values at $5.5 \mathrm{~km}$, the largest layer top height out of the four seasonal mean profiles. The largest mean particle extinction coefficient value in the PBL was $330 \mathrm{Mm}^{-1}$.

The mean May-June profile was calculated from 33 single profiles and shows increased particle extinction coefficient values between 1 and $2.5 \mathrm{~km}$ height. Here, the lofted layers were located at lower altitudes than in the mean spring profile. There was less aerosol as well. The maximum value of the mean particle extinction coefficient in the PBL was $310 \mathrm{Mm}^{-1}$.

In total, the mean particle extinction coefficient profiles show that particles are present in lofted layers that reach up to heights of around $5 \mathrm{~km}$. During spring these lofted layers even reached up to a mean value of $5.5 \mathrm{~km}$. In the following discussion the focus is laid on these lofted layers to identify the aerosol types they contain.

\section{Lofted aerosol layers}

The top heights and the depths of the lofted aerosol layers are shown in Fig. 6. Both values were identified visually using the backscatter coefficient profiles. The top height is defined to the altitude where the backscatter coefficient reaches the molecular background. The lower boundary of the lofted layer is set to the minimum in the backscatter coefficient profile between the PBL and the lofted layer. The top heights range from a few cases of $1.5 \mathrm{~km}$ to heights of $5 \mathrm{~km}$. The highest frequency of occurrences was observed from 2 to $3 \mathrm{~km}$, with a second smaller peak at 4 and $4.5 \mathrm{~km}$. 

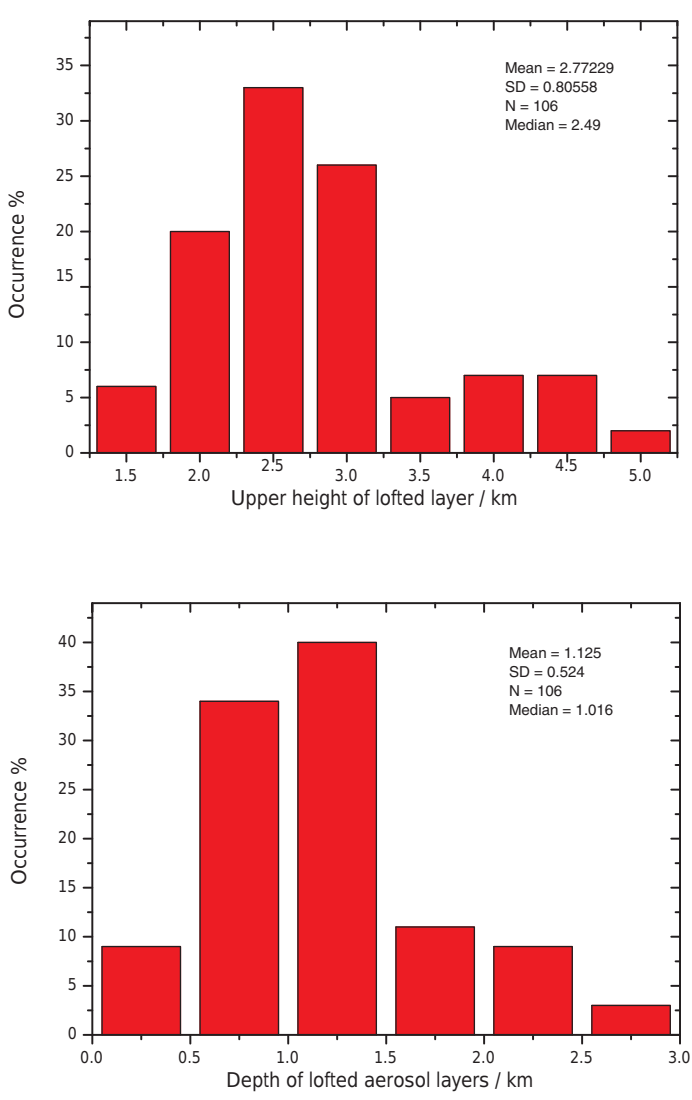

Figure 6. Histogram of lofted-layer heights and depths.

During the winter season (November 2011 to midFebruary 2012), mostly the low top heights of the lofted layers below $2.5 \mathrm{~km}$ were observed and only a few cases with higher top heights occurred. The highest aerosol layer tops were observed during the spring season (end of February, March, and April). In total, 21 cases of lofted layers with top heights of $3.5 \mathrm{~km}$ and higher occurred. During the summer months May and June, the top heights were always between 2.5 and $3 \mathrm{~km}$ height. In total, a variability of the top heights of lofted layers from 1.5 to $5 \mathrm{~km}$ was observed, with a majority of 79 cases between 2 and $3 \mathrm{~km}$.

The depths of the observed lofted layers range from a few cases with less than $0.5 \mathrm{~km}$ up to cases of $3 \mathrm{~km}$. The maximum frequency of occurrence with 74 cases lay between 0.5 and $1.5 \mathrm{~km}$, and in 23 cases the depth of the lofted layer was between 1.5 and $3 \mathrm{~km}$.

\subsection{Lofted-layer AOD}

The lidar profiles of the case study shown in Fig. 3 are an example for very high aerosol content. The AOD measurements on this day were among the highest values during the entire observation period: 1.04 at $355 \mathrm{~nm}$ and 0.60 at $532 \mathrm{~nm}$. The AOD inside the lofted layer was 0.76 at $355 \mathrm{~nm}$ and 0.47 at $532 \mathrm{~nm}$. The AOD ratio, which is the ratio of the AOD inside the lofted layer to the total AOD, is $73 \%$ at $355 \mathrm{~nm}$ and $78 \%$ at $532 \mathrm{~nm}$ in this case. This is partly due to the low AOD inside the lower layers on this day since the PBL is rather clean at this time of the night. However, 2 days before, on 24 and 25 March (see Fig. 2), when the PBL was not so clean, the AOD ratio for the lofted layers was about $70 \%$.

The mean AOD for the lofted layers for each month and some seasonal periods is presented in Table 1 . The mean AOD ratio for the lofted layer in March is the highest ratio with $56 \%$. Also, April and June show high AOD ratios with 48 and $44 \%$, respectively, while the AOD ratio for May is only $26 \%$. During the winter months November, December, and January, the AOD ratio is between 12 and $18 \%$, while in February, with $22 \%$, it is already a bit higher. This is also due to three observations with higher aerosol content in the lofted layers at the end of the month. When counting these profiles for the spring period, the winter mean AOD ratio is $15 \%$ and the spring mean AOD ratio is $48 \%$. For the 2 summer months, the mean AOD ratio is $34 \%$. For the whole observation period, the mean AOD ratio for the lofted layers is $32 \%$.

Thus, a significant part of the aerosol over the PRD is present at high altitudes - especially during spring and summer. It can be concluded that the aerosol can remain in these upper layers for some days before it is washed out by rain or is diluted by transport processes.

\subsection{Aerosol classification}

The lidar optical properties used to characterize the aerosol type of the observed particles are the lidar ratio, the linear particle depolarization ratio, and the Ångström exponent. In Fig. 7, the mean value of the lidar ratio at $532 \mathrm{~nm}$ is plotted versus the linear particle depolarization ratio at $532 \mathrm{~nm}$ (a) and the backscatter-related Ångström exponent at 355$532 \mathrm{~nm}$ (b) for all observed lofted layers. For each data point the lidar measurements lasted over at least $2 \mathrm{~h}$. Each month has been coded by a colour for easier identification. Figure $7 \mathrm{a}$ shows that most data points range between lidar ratios of 30 and $80 \mathrm{sr}$, while the linear depolarization ratio remains mainly below $10 \%$, and for the majority of cases even below $5 \%$. This means that most of the time spherical particles were observed. Depolarization ratios below $5 \%$ and high lidar ratios of up to $80 \mathrm{sr}$ are caused by particles of low scattering and high absorption capabilities. These are most likely freshly produced smoke and pollution particles arising from local sources. This is true for the observations during winter and also for May and June. In March and April the depolarization ratio lies more often between 5 and $10 \%$ and the corresponding lidar ratios are between 40 and 60 sr. These properties fit to more aged particles and may be a result of the longer residence time of the particles inside the lofted layers during this time of year. They may also indicate traces of dust (e.g. agricultural dust, road dust, or dust from biomass burning fires injected into the atmosphere) or other large, non- 

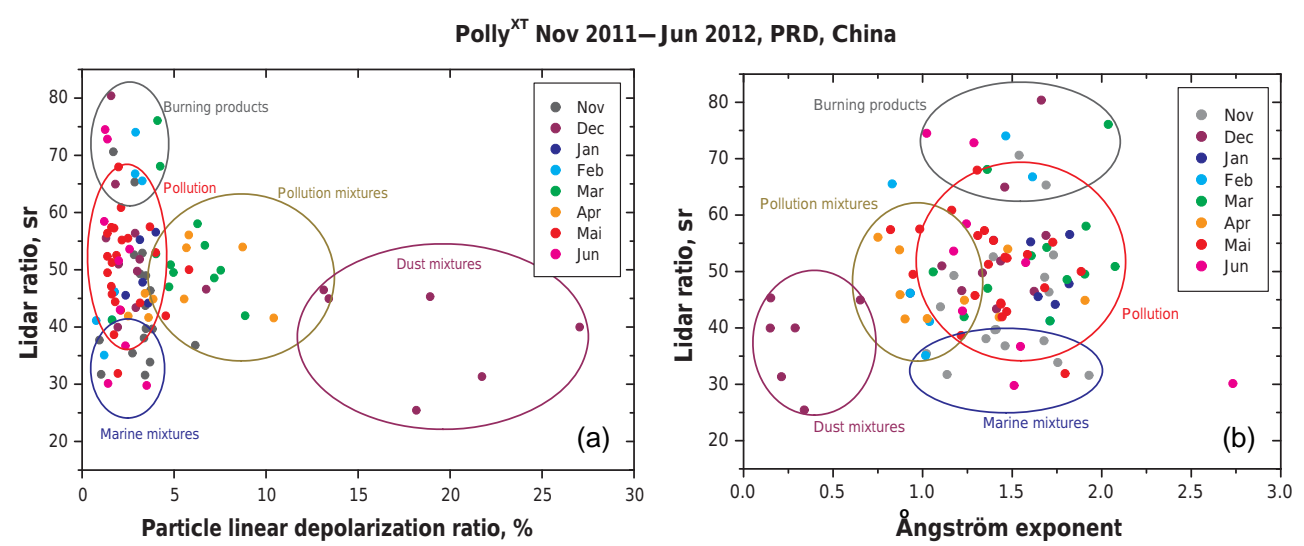

Figure 7. Aerosol classification using lidar ratio at $532 \mathrm{~nm}$ versus linear particle depolarization (a) and the Ångström exponent related to the linear particle backscatter coefficient at 355-532 nm (b) for lofted layers from November 2011 to June 2012. The coloured circles indicate the identified particle mixtures and corresponding measurements.

Table 1. Monthly mean values of total AOD and AOD of identified lofted layers derived from lidar extinction profiles. There were 19 profiles used for November, 24 for December, 5 for January, 6 for February, 12 for March, 9 for April, 21 for May, and 10 for June. The total number of profiles is 106 .

\begin{tabular}{lrrr}
\hline Period & Total AOD & Layer AOD-LL & Percentage \\
\hline Nov 2011 & $0.49 \pm 0.29$ & $0.06 \pm 0.05$ & $12.2 \%$ \\
Dec 2011 & $0.39 \pm 0.26$ & $0.07 \pm 0.09$ & $18.0 \%$ \\
Jan 2012 & $0.24 \pm 0.07$ & $0.03 \pm 0.02$ & $12.5 \%$ \\
Feb 2012 & $0.67 \pm 0.46$ & $0.15 \pm 0.11$ & $22.4 \%$ \\
Mar 2012 & $0.84 \pm 0.27$ & $0.47 \pm 0.19$ & $55.9 \%$ \\
Apr 2012 & $0.60 \pm 0.41$ & $0.29 \pm 0.29$ & $48.3 \%$ \\
May 2012 & $0.34 \pm 0.26$ & $0.09 \pm 0.12$ & $26.5 \%$ \\
Jun 2012 & $0.36 \pm 0.21$ & $0.16 \pm 0.16$ & $44.4 \%$ \\
\hline Nov 2011 to Feb 2012 & $0.40 \pm 0.27$ & $0.06 \pm 0.07$ & $15.0 \%$ \\
Feb 2012 to Apr 2012 & $0.77 \pm 0.34$ & $0.37 \pm 0.24$ & $48.2 \%$ \\
May 2012 to Jun 2012 & $0.35 \pm 0.24$ & $0.12 \pm 0.14$ & $34.3 \%$ \\
Nov 2011 to Jun 2012 & $0.47 \pm 0.32$ & $0.15 \pm 0.19$ & $32.0 \%$ \\
\hline
\end{tabular}

spherical particles, e.g. dried marine particles. Only a few cases of high linear depolarization ratios $>10 \%$ were observed. The highest values of more than $20 \%$ were measured on 2 and 3 December 2011 during the only dust advection event that took place during the measurement period. This event, where the dust arrived from the desert areas north of China, was discussed in detail in Heese et al. (2012).

Further classification can be performed by using the sizedependent information given through the Ångström exponents. As an example, the backscatter-related Ångström exponent at $355-532 \mathrm{~nm}$ is shown in Fig. $7 \mathrm{~b}$. The two other Ångström exponents show a comparable behaviour. It can be seen that the majority of Ångström exponents lie between 1 and 1.5 at lidar ratios between 40 and 60 sr. These properties indicate particles from urban pollution of small and medium size. Pollution mixed with larger particles can be identified by lidar ratios around $50 \mathrm{sr}$ and Ångström exponents down to 0.5 . Lidar ratios below $40 \mathrm{sr}$ indicate that marine parti- cles may be mixed with the pollution particles. Pure marine particles are larger and would have a lower Ångström exponent of 0.1 to 0.3 (Müller et al., 2007). Another group of observed high Ångström exponents from 1.3 to 2, with lidar ratios from 60 to $80 \mathrm{sr}$ and low depolarization ratios, are identified as more absorbent with smaller particles from burning processes, which contain soot.

These results are consistent with findings from former studies. Tesche et al. (2007) measured high levels of aerosol pollution over the PRD in October 2006, with lidar ratios between 40 and $55 \mathrm{sr}$ and mean value of $47 \pm 6 \mathrm{sr}$. Ansmann et al. (2005) concluded that these lidar ratios are consistent with the presence of large, absorbent particles.

Baars et al. (2016) evaluated the derived optical properties for all available Polly ${ }^{\text {NET }}$ measurements performed with several Polly ${ }^{\mathrm{XT}}$ instruments at different sites worldwide until 2014 (for more details see http://polly.tropos.de). From their study they found linear depolarization ratios below $5 \%$ at 
355 and $532 \mathrm{~nm}$ and corresponding lidar ratios between 30 and $80 \mathrm{sr}$ for urban particles and particles arising from burning processes.

Groß et al. (2015) report a mean linear depolarization ratio of $6 \pm 1 \%$ and a mean lidar ratio of $56 \pm 6$ sr for anthropogenic pollution in their aerosol classification scheme at $532 \mathrm{~nm}$, derived from several field campaigns.

A summary of lidar optical properties at $355 \mathrm{~nm}$ that will be used for the particle classification scheme for the upcoming EarthCARE satellite is presented in Illingworth et al. (2015). They also report linear depolarization ratios below $5 \%$ for smoke plumes and anthropogenic pollution and lidar ratios from 30 to 80 and from 45 to $65 \mathrm{sr}$, respectively.

A study by Cattrall et al. (2005) used AERONET sites for aerosol classification and found that particle optical properties over south-eastern Asia are distinct from those over other urban and industrial centres, owing to a greater number of large particles relative to fine particles.

In summary, we can conclude that particles of urban pollution arising from traffic, combustion of fuel, industry, and other burning processes are dominant over the PRD. Dust advection only plays a minor role, which was already observed by the Asian dust lidar network (e.g. Nishizawa et al., 2010).

\subsection{Origin of the aerosol layers - trajectory analysis}

A backward trajectory analysis was performed using the HYSPLIT model (Stein et al., 2015) to determine the origin and the sources of the observed aerosol layers. Backward trajectories were calculated for $144 \mathrm{~h}$ for the periods of all evaluated lidar profiles. In most cases three arrival heights were sufficient to cover the vertical aerosol structure, but in a few cases in which the aerosol extended up to very high altitudes, up to 5 arrival heights were necessary. Arrival heights were set to the middle of an existing aerosol layer. From this analysis, a total of 413 backward trajectories were obtained and a cluster analysis was performed to identify the main regions of the particle sources. For the cluster analysis all backward trajectories were divided into arrival heights below and above $1200 \mathrm{~m}$ to separate the PBL and the lofted aerosol layers. Additionally, the lofted layers observed at very high altitudes above $3500 \mathrm{~m}$ were analysed separately since they show a seasonal dependence and occurred mainly in spring. In the following paragraphs the results for these three layer categories are presented.

\subsubsection{Lower layers - PBL}

For this category the lowermost layers with a top height reaching up to a maximum of $1200 \mathrm{~m}$ were considered. This covers mainly the PBL, and only a few cases of very low lofted layers may be included. Five clusters were calculated (Fig. 8 a). Most of the trajectories arriving at these layers came from local and regional sources. Of these local and regional trajectories, $37 \%$ came from a north-easterly direc-
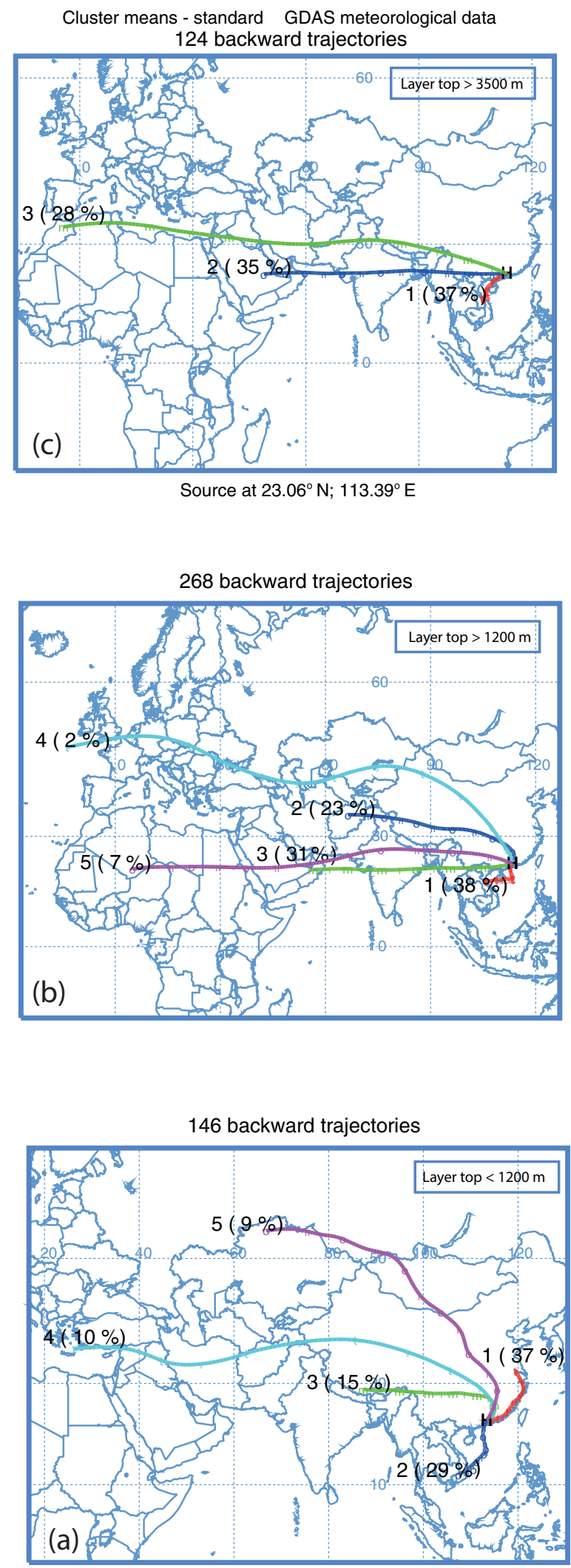

Figure 8. Trajectory cluster means for (a) PBL top heights up to $1200 \mathrm{~m}$, (b) all lofted layers above $1200 \mathrm{~m}$, and (c) lofted layers with top height above $3500 \mathrm{~m}$. All trajectories were calculated $144 \mathrm{~h}$ back in time. 

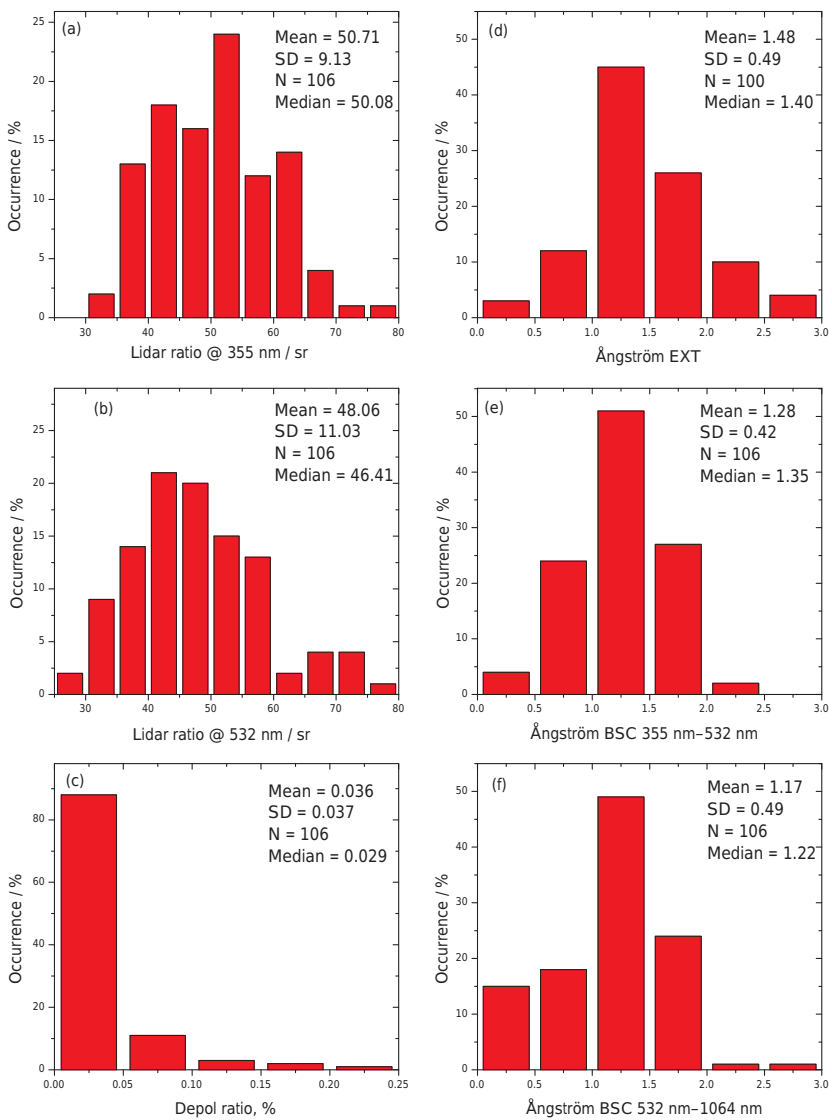

Figure 9. Statistical analysis of the optical properties of the observed lofted aerosol layers: (a) lidar ratio at $355 \mathrm{~nm}$, (b) lidar ratio at $532 \mathrm{~nm}$, (c) linear particle depolarization ratio at $532 \mathrm{~nm}$, (d) extinction-related Ångström exponent at 355-532 nm, (e) backscatter-related Ångström exponent at 355-532 nm, (f) and backscatter-related Ångström exponent at 532-1064 nm.

tion (cluster 1), $29 \%$ came from a south-westerly direction (cluster 2), and $15 \%$ came from a westerly direction (cluster 3). Only about a fifth of all trajectories came from regions further away: $10 \%$ of the trajectories came from a westerly direction (cluster 4), reaching back to the Arabian and Saharan deserts and $9 \%$ of the trajectories (cluster 5) came from a north-westerly direction, originating from the areas north of China. This is a result that was expected for the lower altitudes above the PRD. Most air masses were of local origin, either from the mainland or from the close sea.

\subsubsection{Lofted layers}

The air masses arriving at the layers above $1200 \mathrm{~m}$ mainly came from the westerly and north-westerly directions (Fig. 8b): $23 \%$ of the air masses came from north-westerly regions (cluster 2) and $31 \%$ came from closer sources from the west (cluster 3). Only $7 \%$ of the trajectories indicates a possible distant source arriving from westerly directions (cluster 5) and only $2 \%$ of the trajectories came from far
Table 2. Summary of lidar mean optical properties for the lofted aerosol layers measured over the PRD region.

\begin{tabular}{lr}
\hline Property & Mean \pm SD \\
\hline AOD-LL 532 nm & $0.15 \pm 0.19$ \\
Lidar ratio 355 nm (sr) & $50.7 \pm 9.1$ \\
Lidar ratio 532 nm (sr) & $48.1 \pm 11.0$ \\
Ång EXT 355-532 nm & $1.48 \pm 0.49$ \\
Ång BSC 355-532 nm & $1.28 \pm 0.42$ \\
Ång BSC 532-1064 nm & $1.17 \pm 0.49$ \\
Depol ratio (\%) & $3.6 \pm 3.7$ \\
\hline
\end{tabular}

sources from the north-west (cluster 4). Also, for this category we can conclude that the majority of the aerosol burden originated from local sources that are close to or inside the PRD region.

\subsubsection{Highest layers}

A separate cluster analysis was performed for the highest observed layers above $3500 \mathrm{~m}$. Here, only three clusters were calculated. However, the behaviour of these trajectories is comparable to lofted-layer trajectories. Of the trajectories, $35 \%$ came from a westerly direction (cluster 3 ), $28 \%$ of the trajectories came from a slightly more north-westerly direction (cluster 2), and, again, $37 \%$ of the trajectories came from local regions (cluster 1, Fig. 8c). Thus, no significant difference concerning the origin was found for the particle layers observed up to very high altitudes in March and April 2012 compared to the lower lofted layers.

In summary we can conclude that only a very low percentage of aerosol is transported to the PRD from sources further away. About one-third of all trajectories show air mass transport from close by, even if they were calculated for 6 days.

\subsection{Statistics of lofted-layer optical properties}

In order to give a comprehensive overview of the typical aerosol conditions in the PRD, a statistical analysis of the measured optical properties of the observed lofted aerosol layers is given in the following. Statistical results are of importance if the data will be used for further analyses, for example for modelling studies. In Fig. 9, the mean and median values and the standard deviations were calculated for the following properties: the lidar ratios at $355 \mathrm{~nm}$ (a) and $532 \mathrm{~nm}$ (b), the linear particle depolarization ratio at $532 \mathrm{~nm}$ and the Angström exponents related to the extinction coefficient at $355-532 \mathrm{~nm}(\mathrm{~d})$, the particle backscatter coefficient at $355-532 \mathrm{~nm}(\mathrm{e})$, and the particle backscatter coefficient at 532-1064 nm (f).

The statistics of the lidar ratios show a wide range of values from 30 to $80 \mathrm{sr}$ for both wavelengths (Fig. 9a and b). Most of the lidar ratios lie between 30 and $60 \mathrm{sr}$, with a peak value of $50-55 \mathrm{sr}$ at $355 \mathrm{~nm}$ and $40-50 \mathrm{sr}$ at $532 \mathrm{~nm}$. 
The mean lidar ratio at $355 \mathrm{~nm}$ is $50.7 \mathrm{sr}$ and slightly higher than the mean lidar ratio at $532 \mathrm{~nm}$ of $48.1 \mathrm{sr}$. These values confirm the rare and formerly very short lidar measurements in the PRD region. From the first Megacities campaign in November 2009 (Chen at al., 2014), only lidar ratios at $355 \mathrm{~nm}$ were measured. They were $64 \pm 10 \mathrm{sr}$ for a hazy period and $56 \pm 9 \mathrm{sr}$ for a moderately polluted period. Lidar ratios at $532 \mathrm{~nm}$ were measured in Xinken (PRD) in October 2004 , and the mean value of the lidar ratio was $46.7 \pm 5.6 \mathrm{sr}$ (Ansmann et al., 2005; Tesche et al., 2007).

As already seen in the aerosol classification (Fig. 9c), the statistics of linear particle depolarization ratio at $532 \mathrm{~nm}$ show that for the majority of 89 cases the depolarization ratio was below $5 \%$, and only 11 cases lie between 5 and $10 \%$. In only six cases was the depolarization ratio higher than $10 \%$. This implies that mostly spherical particles were present and that non-spherical particles are seldom mixed into the aerosol. The mean value for the linear depolarization ratio is $3.6 \pm 3.7 \%$.

The histogram of the Angström exponent related to the particle extinction coefficient at 355-532 nm (Fig. 9d) shows a few cases of low values below 1 , a peak of 45 cases between 1.0 and 1.5 , and a smaller peak of 26 cases from 1.5 to 2 . Even higher values up to 3.0 were observed in 14 cases. The mean value for the extinction-related Angström exponent is $1.48 \pm 0.49$.

The Angström exponents related to the particle backscatter coefficients at 355-532 nm (Fig. 9e) and 532-1064 nm (Fig. 9f) show a comparable distribution. Most cases, 51 and 49, respectively, lie between 1.0 and 1.5 , and 27 and 24 cases, respectively, lie between 1.5 and 2.0. Only two cases lie above 2.0. Below 1.0, however, the number of cases is slightly higher for the particle-backscatter-related Ångström exponent at 532-1064 nm, and especially the number of cases below 0.5 . is higher. The mean values for the backscatter-related Ångström exponent are $1.28 \pm 0.42$ at $355-532 \mathrm{~nm}$ and $1.17 \pm 0.49$ at $532-1064 \mathrm{~nm}$. Only a few cases show Ångström exponents below 0.5, which indicates larger particles in the coarse mode. This is consistent with the few observed cases of linear particle depolarization ratios above $10 \%$. The derived mean particle optical properties are summarized in Table 2.

\section{Conclusions}

For the first time, continuous multi-wavelength Raman and polarization lidar observations were performed over a longterm period in the highly polluted atmosphere of the Pearl River Delta, Guangzhou, China. The measurements were taken from November 2011 to mid-June 1012. The observations show that a high load of aerosol is present not only in the planetary boundary layer but also in lofted layers that reach up to several kilometres height. The heights of these lofted layers show a seasonal dependence, with heights be- low $2 \mathrm{~km}$ during winter and very high layer top heights above $5 \mathrm{~km}$ in spring. The aerosol optical depth in the lofted layers make a significant part of the total AOD observed in the vertical profile. The total AOD rises from monthly mean winter values of 0.49 in November to 0.84 in March. The percentage of the AOD in the lofted layers varies from 12-20\% in the winter months to $48-55 \%$ in spring.

These results confirm a previous study by Wang et al. (2011), who investigated seasonal variations of AOD over different locations in China using the Chinese Sun Hazemeter Network. In most parts of China, AOD values are at a maximum in spring or summer and at a minimum in autumn or winter. This was also observed in Guangzhou and is consistent with the general wind circulation dominated by the Asian monsoon.

A classification of the observed aerosol in the lofted layers over the PRD using the lidar optical properties shows mostly low linear particle depolarization ratios and a wide range of lidar ratios. These properties indicate that mainly particle mixtures of urban pollution arising from traffic, combustion of fuel, industry, and other burning processes are present in these layers. These particles are mainly locally and regionally produced. During the summer monsoon season, they may also be mixed with particles of marine origin from the close-by sea. Dust mixture into the pollution aerosol transported from sources further away was only observed in one case.

Data availability. AERONET sunphotometer data measured in Guangzhou can be downloaded at aeronet.gsfc.nasa.gov/cgi-bin/ type_one_station_opera_v2_new?site=Zhongshan_Univ.

The trajectories were calculated with the NOAA (National Oceanic and Atmospheric Administration) HYSPLIT (HYbrid Single-Particle Lagrangian Integrated Trajectory) model that is publicly available at http://ready.arl.noaa.gov/HYSPLIT_traj.php using GDAS meteorological data. The resulting trajectory data are available from a data server at TROPOS.

For the lidar data molecular corrections radio sounding data from Kings Park, Hong Kong, were used. They can be accessed from the website of the University of Wyoming (http://weather.uwyo.edu/ upperair/sounding.html).

Quick-looks of the lidar measurements taken in Guangzhou can be viewed at http://polly.rsd.tropos.de/?p=lidarzeit\&Ort=23. The lidar data are available from a server at TROPOS. Please contact Birgit Heese (heese@tropos.de) for inquiries.

Competing interests. The authors declare that they have no conflict of interest.

Acknowledgements. The measurements were conducted in the framework of the special priority program "MegacitiesMegachallenges - Informal Dynamics of Global Change" (SPP 1233) funded by the German Research Foundation (DFG). 
We thank our colleagues from the Sun Yat-sen University, Guangzhou, for their support throughout the measurement campaign.

Edited by: U. Baltensperger

Reviewed by: two anonymous referees

\section{References}

Althausen, D., Engelmann, R., Baars, H., Heese, B., Ansmann, A., Müller, D., Komppula, M.: Portable Raman lidar Polly XT for automated profiling of aerosol backscatter, extinction, and depolarization, J. Atmos. Ocean. Tech., 47, 2366-2378, 2009.

Ansmann, A., Wandinger, U., Riebesell, M., Weitkamp, C., and Michaelis, W.: Independent measurement of extinction and backscatter profiles in cirrus clouds by using a combined Raman elastic-backscatter lidar, Appl. Optics, 31, 7113-7131, 1992.

Ansmann A., Engelmann, R., Althausen, D., Wandinger, U., $\mathrm{Hu}, \mathrm{M}$., Zhang, Y., and He, Q.: High aerosol load over the Pearl River Delta, China, observed with Raman lidar and sun photometer, Geophys. Res. Lett., 32, L13815, https://doi.org/10.1029/2005GL023094, 2005.

Baars, H., Kanitz, T., Engelmann, R., Althausen, D., Heese, B., Komppula, M., Preißler, J., Tesche, M., Ansmann, A., Wandinger, U., Lim, J.-H., Ahn, J. Y., Stachlewska, I. S., Amiridis, V., Marinou, E., Seifert, P., Hofer, J., Skupin, A., Schneider, F., Bohlmann, S., Foth, A., Bley, S., Pfüller, A., Giannakaki, E., Lihavainen, H., Viisanen, Y., Hooda, R. K., Pereira, S. N., Bortoli, D., Wagner, F., Mattis, I., Janicka, L., Markowicz, K. M., Achtert, P., Artaxo, P., Pauliquevis, T., Souza, R. A. F., Sharma, V. P., van Zyl, P. G., Beukes, J. P., Sun, J., Rohwer, E. G., Deng, R., Mamouri, R.-E., and Zamorano, F.: An overview of the first decade of PollyNET: an emerging network of automated Raman-polarization lidars for continuous aerosol profiling, Atmos. Chem. Phys., 16, 5111-5137, https://doi.org/10.5194/acp16-5111-2016, 2016.

Boening, C., Willis, J. K., Landerer, F. W., Nerem, R. S., and Fasullo, J.: The 2011 La Niña: So strong, the oceans fell, Geophys. Res. Lett., 39, L19602, https://doi.org/10.1029/2012GL053055, 2012

Cattrall, C., Reagan, J., Thome, K., and Dubovik, O.: Variability of aerosol and spectral lidar and backscatter and extinction ratios of key aerosol types derived from selected Aerosol Robotic Network locations, J. Geophys. Res., 110, D10S11, https://doi.org/10.1029/2004JD005124, 2005.

Chan, C. K. and Yao, X.: Air pollution in mega cities in China, Atmos. Environ., 42, 1-42, https://doi.org/10.1016/j.atmosenv.2007.09.003, 2008.

Chen, Z., Liu, W., Heese, B., Althausen, D., Baars, H., Cheng, T., Shu, X., and Zhang, T.: Aerosol optical properties observed by combined Raman-elastic backscatter lidar in winter 2009 in Pearl River Delta, south China, J. Geophys. Res., 119, 2496-2510, https://doi.org/10.1002/2013JD020200, 2014.

Climate Data: https://en.climate-data.org/ (last access: 26 May 2017), 2012

Deng, X., Tie, X., Wu, D., Zhou, X., Bi, X., Tan, H., Li, F., and Jiang, C.: Long-term trend of visibility and its characterizations in the Pearl River Delta (PRD) region, China, Atmos. Environ.,
42, 1424-1435, https://doi.org/10.1016/j.atmosenv.2007.11.025, 2008.

Engelmann, R., Kanitz, T., Baars, H., Heese, B., Althausen, D., Skupin, A., Wandinger, U., Komppula, M., Stachlewska, I. S., Amiridis, V., Marinou, E., Mattis, I., Linné, H., and Ansmann, A.: The automated multiwavelength Raman polarization and water-vapor lidar PollyXT: the neXT generation, Atmos. Meas. Tech., 9, 1767-1784, https://doi.org/10.5194/amt-9-1767-2016, 2016.

Fernald, F. G.: Analysis of atmospheric lidar observations, Appl. Optics, 23, 652-653, 1984.

Freudenthaler, V., Esselborn, M., Wiegner, M., Heese, B., Tesche, M., Ansmann, A., Müller, D., Althausen, D., Wirth, M., Fix, A., Ehret, G., Knippertz, P., Toledano, C., Gasteiger, J., Garhammer, M., and Seefeldner, M.: Depolarization ratio profiling at several wavelengths in pure Saharan dust during SAMUM 2006, Tellus, 61B, 165-179, 2009.

Groß, S., Freudenthaler, V., Wirth, M., and Weinzierl, B.: Towards an aerosol classification scheme for future EarthCARE lidar observations and implications for research needs, Atmos. Sci. Lett., 16, 77-82, https://doi.org/10.1002/as12.524, 2015.

Hara, Y., Uno, I., Sugimoto, N., Shimizu, A., Matsui, I., Yumimoto, K., Kurokawa, J.-I., Ohara, T., and Liu, Z.: Seasonal Characteristics of Spherical Aerosol Distribution in Eastern Asia:Integrated Analysis Using Ground/Space-Based Lidars and a Chemical Transport Model, SOLA, 7, 212-124, https://doi.org/10.2151/sola.2011-031, 2011.

Heese, B., Althausen, D., Bauditz, M., Bao, R., Deng, R., and Li, Z.: Lidar depolarization and sun photometer polarization measurements for particle characterization over Guangzhou, China, Proceedings of the 26th ILRC, Porto Heli, Greece, 25-29 June, 505-509, 2012.

Holben, B. N., Eck, T. F., Slutsker, I., Tanre, D., Buis, J. P., Setzer, A., Vermote, E., Reagan, J. A., Kaufman, Y., Nakajima, T., Lavenu, F., Jankowiak, I., and Smirnov, A.: AERONET - A federated instrument network and data archive for aerosol characterization, Remote Sens. Environ., 66, 1-16, 1998.

Illingworth, A. J., Barker, H. W., Beljaars, A., Ceccaldi, M., Chepfer, H., Clerbaux, N., Cole, J., Delanoë, J., Domenech, C., Donovan, D. P., Fukuda, S., Hirakata, M., Hogan, R. J., Huenerbein, A., Kollias, P., Kubota, T., Nakajima, T., Nakajima, T. Y., Nishizawa, T., Ohno, Y., Okamoto, H., Oki, R., Sato, K., Satoh, M., Shephard, M. W., Velázquez-Blázquez, A., Wandinger, U., Wehr, T., and van Zadelhoff, G.-J.: The EarthCARE Satellite: The Next Step Forward in Global Measurements of Clouds, Aerosols, Precipitation, and Radiation, B. Am. Meteorol. Soc., 96, 1311-1332, https://doi.org/10.1175/BAMS-D-12$00227.1,2015$

Klett, J. D.: Stable analytical inversion solution for processing lidar returns, Appl. Optics, 20, 211-220, 1981.

Li Z., Goloub, P., Dubovik, O., Blarel, L., Zhang, W., Podvin, T., Sinyuk, A., Sorokin, M., Chen, H., Holben, B., Tanré, D., Canini, M., and Buis, J.-P.: Improvements for ground-based remote sensing of atmospheric aerosol properties by additional polarimetric measurements, J. Quant. Spectrosc. Ra., 110, 1954-1961, 2009.

National Climatic Data Center: Meteorological station No. 592870, https://www.ncdc.noaa.gov/data-access (last access: 9 January 2013), 2012. 
Müller, D., Ansmann, A., Mattis, I., Tesche, M., Wandinger, U., Althausen, D., and Pisani, G.: Aerosol-type-dependent lidar ratios observed with Raman lidar, J. Geophys. Res., 112, D16202, https://doi.org/10.1029/2006JD008292, 2007.

Murayama T., Sugimoto, N., Uno, I., Kinoshita, K., Aoki, K., Hagiwara, N., Liu, Z., Matsui, I., Sakai, T., Shibata, T., Arao, K., Sohn, B.-J., Won, J.-G., Yoon, S.-C., Li, T., Zhou, J., Hu, H., Abo, M., Iokibe, K., Koga, R., and Iwasakaet, Y.: Ground-based network observations of Asian dust events of April 1998 in east Asia, J. Geophys. Res., 106, 18345-18359, https://doi.org/10.1029/2000JD900554, 2001.

Nishizawa, T., Sugimoto, N., Matsuia, I., Shimizua, A., Liub, X., Zhangb, Y., Lic, R., and Liuc, J.: Vertical distribution of water-soluble, sea salt, and dust aerosols in the planetary boundary layer estimated from two-wavelength backscatter and one-wavelength polarization lidar measurements in Guangzhou and Beijing, China, Atmos. Res., 96, 602-611, https://doi.org/10.1016/j.atmosres.2010.02.002, 2010.
Stein, A. F., Draxler, R. R, Rolph, G. D., Stunder, B. J. B., Cohen, M. D., and Ngan, F.: NOAA's HYSPLIT atmospheric transport and dispersion modeling system, B. Am. Meteorol. Soc., 96, 2059-2077, https://doi.org/10.1175/BAMS-D-14$00110.1,2015$.

Sugimoto, N., Nishizawa, T., Liu, X., Matsui, I., Shimizu, A., Zhang, Y., Kim, Y. J., Li, R., and Liu, J.: Continuous Observations of Aerosol Profiles with a Two-Wavelength Mie-Scattering Lidar in Guangzhou in PRD2006, J. Appl. Meteorol. Clim., 48, 1822-1830, https://doi.org/10.1175/2009JAMC2089.1, 2009

Tesche, M., Ansmann, A., Müller, D., Althausen, D., Engelmann, R., Hu, M., and Zhang, Y.: Particle backscatter, extinction, and lidar ration profiling with Raman lidar in South and North China, Appl. Optics, 46, 6302-6308, 2007.

Wang, Y., Xin, J., Li, Z., Wang, S., Wang, P., Hao, W. M., Nordgren, B. L., Chen, H., Wang, L., and Sun, Y.: Seasonal variations in aerosol optical properties over China, J. Geophys. Res., 116, D18209, https://doi.org/10.1029/2010JD015376, 2011. 